\title{
DEPENDENCE OF WHITENESS OF DECORATIVE SLAG-ALKALINE CEMENT FROM THE CHEMICAL COMPOSITION OF BLAST-FURNACE SLAGS
}

\author{
${ }^{1}$ Krivenko P.V., Doctor of Technical Sciences, Professor, \\ pavlo.kryvenko@gmail.com, ORCID: 0000-0001-7697-2437 \\ ${ }^{1}$ Gelevera A.G., Ph.D., Associate Professor, \\ a-gelevera@ukr.net, ORCID: 0000-0002-6285-9780 \\ ${ }^{1}$ Kovalchuk A.Yu., Ph.D., Senior Researcher, \\ kovalchuk.oyu@gmail.com, ORCID: 0000-0001-6337-0488 \\ ${ }^{1}$ Rogozina N.V., postgraduate student, \\ knubatbkv@ukr.net, ORCID: 0000-0001-9621-4246 \\ ${ }^{1}$ Kiev National University of Civil Engineering and Architecture \\ Vozduhoflotsky ave., 31, Kiev, 03037, Ukraine
}

\begin{abstract}
The construction industry is demanding more and more quality decorative cements. The demand for them and the requirements for their performance are constantly growing. But since decorative cements are based on white Portland cement, their production is associated with the disadvantages of the production of all clinker cements - low environmental friendliness, high energy consumption and high prices. They are not always able to provide decorative ecological and comfortable coatings with increased performance. In addition, many countries do not produce it and have to import it.

An effective alternative to decorative clinker cements can be decorative slag-alkaline cement obtained from industrial waste. It also provides a number of special properties - a wide range of colors, color fastness, high strength, high adhesion, durability and many others.

But the problem associated with the use of slag-alkaline cements as decorative cements with high linen $(\geq 70 \%)$ is the unstable chemical composition of the slag and, first of all, the different presence of iron oxides in it. It is shown that the presence of iron oxides can reduce the whiteness of decorative slag-alkaline cements due to the synthesis of compounds in them, which give the samples of blue-green color and due to the presence of iron oxides proper, which are inherent in color from brown to dark brown.

The paper shows the regularities of the influence of the chemical composition of blast-furnace slags on the whiteness of an artificial slag-alkaline stone. Possibilities of obtaining decorative alkali-activated cements with a wide range of whiteness - from 70 to $97 \%$ are shown. Methods of reducing the cost of slag-alkaline decorative cements by using a complex bleaching additive, where part of the expensive $\mathrm{TiO}_{2}$ can be replaced by kaolin or $\mathrm{CaCO}_{3}$, are shown. A new method for determining the whiteness of hardened materials is proposed.
\end{abstract}

Keywords: decorative cements, alkali-activated cements, degree of whiteness.

Introduction. Industrial development and safety policies require new building materials that are economical and environmentally friendly. In particular, this applies to decorative cements used to enhance the architectural expressiveness of buildings and to carry out finishing work. The demand for them and the requirements for their performance are constantly growing [1]. Decorative cements are usually made on the basis of white cements [2]. However, such cements have all the disadvantages of Portland cement, including high energy demand, high cost and low environmental friendliness in their production. White Portland cements need to be imported. They, also, are not always able to provide decorative ecological and comfortable coatings with increased performance [3-5]. Decorative slag-alkaline cement produced from industrial waste can be an effective alternative. It also provides a number of special properties - a wide range and color stability, high strength, high adhesion, durability, etc. [6-12]. 
Analysis of recent research. But the problem associated with the use of slag-alkaline cements as decorative cements with high whiteness $(\geq 70 \%)$ is the unstable chemical composition of the slag. In particular, this concerns the presence of iron oxides in it, the content of which can range from $0.13 \%$ to $2.95 \%$. In addition, in the initial periods of hardening, slag-alkali compositions can acquire a blue-green color. In the literature [13], this is associated with the formation of compounds of the $\mathrm{FeSO}_{4} \cdot 7 \mathrm{H}_{2} \mathrm{O}$ type and this was the reason for concerns about the possibility of obtaining white decorative cements on their basis.

In previous studies in this direction [14-16], insufficient attention was paid to the influence of individual additives and their interaction on the decorative and physical-mechanical properties of slag-alkali cements.

Purpose and objectives of research. Based on the analysis of literary sources and theoretical prerequisites, the aim of the work is to study the possibility of effective control of the decorativeness of slag-alkaline cements (slag alkali-activated cements), regardless of the composition of the slags. Research data are aimed at choosing such additives that should have maximum bleaching properties and would enhance the stabilization of bleaching processes during hydration and hardening of slag in the presence of alkalis. The research data are aimed at determining both the individual and the simultaneous effect of several additives on whiteness and physical and mechanical characteristics, as well as determining the optimal content of these additives in slag-alkali decorative compositions.

Materials and research methods. Three types of granulated blast furnace slags were used in the study: Ukrainian metallurgical plants (slag $\mathrm{M}$ and slag $\mathrm{K}$ ) and one - from the Russian Federation (slag T). All slags were ground in a ceramic mill to obtain a specific surface area of $4500 \mathrm{~cm}^{2} / \mathrm{g}$ (according to Blaine). All investigated slags had a glass content in the range from 50 to $60 \%$. The chemical composition of the studied slags is shown in Table 1.

Table 1 - Chemical composition of slag

\begin{tabular}{|c|c|c|c|c|c|c|c|c|c|c|c|c|}
\hline \multirow{2}{*}{$\begin{array}{l}\text { Slag } \\
\text { type }\end{array}$} & \multicolumn{9}{|c|}{ Main oxides content, $\%$ by mass } & \multirow[b]{2}{*}{$\Sigma$} & \multirow[b]{2}{*}{$\mathrm{M}_{\mathrm{b}}$} & \multirow[b]{2}{*}{$\mathrm{M}_{\mathrm{a}}$} \\
\hline & $\mathrm{CaO}$ & $\mathrm{MgO}$ & $\mathrm{Al}_{2} \mathrm{O}_{3}$ & $\mathrm{SiO}_{2}$ & $\mathrm{MnO}$ & $\mathrm{SO}_{3}$ & $\mathrm{FeO}$ & $\begin{array}{l}\mathrm{Na}_{2} \mathrm{O} \\
+\mathrm{K}_{2} \mathrm{O}\end{array}$ & $\mathrm{TiO}_{2}$ & & & \\
\hline Slag T & 43.5 & & 7.0 & 43 & .054 & - & 0.42 & - & 0.26 & 100.53 & 1.00 & 0.16 \\
\hline Slag M & 47.0 & 4.6 & 6.8 & 38.9 & 0.55 & 1.8 & 0.35 & - & - & 100.00 & 1.13 & 0.17 \\
\hline Slag K & 48.5 & 4.6 & 4.6 & 38.2 & 0.81 & 1.1 & 1.65 & 0.79 & - & 100.25 & 1.24 & 0.12 \\
\hline
\end{tabular}

A low-hygroscopic alkaline compound - sodium metasilicate pentahydrate $\mathrm{Na}_{2} \mathrm{O} \cdot \mathrm{SiO}_{2} \cdot 5 \mathrm{H}_{2} \mathrm{O}$ was used as an alkaline component.

Titanium dioxide $\left(\mathrm{TiO}_{2}\right)$, $\mathrm{KH} 84$ class kaolin used in the paper industry with a whiteness of $84 \%$, and calcium carbonate $\left(\mathrm{CaCO}_{3}\right)$ in powder form with a whiteness of $90 \%$ were used as bleaching additives.

Determination of the whiteness of decorative slag alkali-activated cements was carried out by scanning the surface of the cement samples with high resolution and then measuring the whiteness by comparison with a reference sample with a whiteness of $98 \%$ in PhotoShop Soft.

Technological and physical-mechanical properties of slag alkali-activated cements were determined in accordance with the current Ukrainian standards.

\section{Research results.}

Mechanical characteristics of slag alkaline-activated cements. At the first stage of the research, the compressive strength of the slag-alkaline cement was determined depending on the amount of the alkaline component. Slag (M) was assigned as the base aluminosilicate component of slag-alkaline cement for comparison with other slags based on the minimum content of iron oxides in it.

The compressive strength of slag-alkaline cement is shown in Fig.1. 


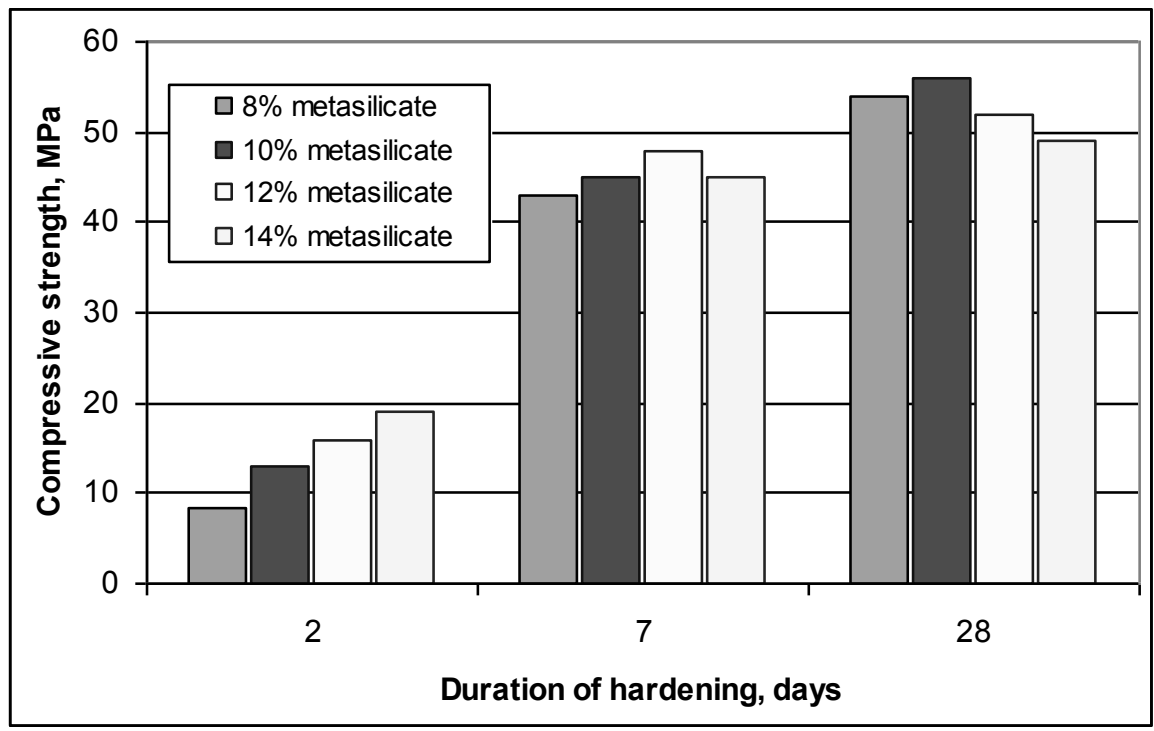

Fig. 1. Compressive strength of slag-alkaline cement depending on the content of the alkaline component. Slag type - M

The analysis of the given results showed that all compositions meet the requirements for cement of strength classes 42.5...52.5. High values were achieved with an alkaline activator content of 8 and $10 \%$ by weight - they turned out to be almost the same at the age of 28 days and both cement compositions met the requirements for cements of strength class 52.5. The results of the study show that the compressive strength after 28 days decreases with an increase in the content of sodium metasilicate by more than $10 \%$.

Considering the higher early strength (after 2 days) of the cement containing $10 \mathrm{wt} \%$ sodium metasilicate, it was chosen for further research.

Whiteness of slag-alkali cements. The next stage of the study was to test the brightness of alkali-activated slag cements made from three slags, and to investigate possible ways to increase it by adding bleaching additives such as $\mathrm{TiO}_{2}, \mathrm{CaCO}_{3}$ and kaolin clay with a high degree of disease. In the studies, the following limits were adopted for varying the amount of bleaching additives in cement: $\mathrm{TiO}_{2}$ from 2.5 to $7.5 \%$ by weight, kaolin clay from 5 to $15 \%$ by weight and $\mathrm{CaCO}_{3}$ from 15 to $25 \%$ by weight.

The results of the study of whiteness degree of the investigated slag-alkaline cements are shown in Fig. 2.

Analysis of the above results allowed us to reveal that slag alkali-activated cements based on slag (T) and slag (M) adhered to similar patterns, and the best bleaching effect for these two cement compositions was achieved with the addition of $\mathrm{TiO}_{2}$. Slag (K) showed the lowest whiteness characteristic of all cement compositions. The best whitening result was obtained with calcium carbonate, but it was close to the system without any bleaching agents. All other additives showed a decrease in cement performance by whiteness.

The obtained data on the degree of whiteness for a part of the investigated slag alkaliactivated cements indicate that they meet the requirements for decorative materials, that is, they have a whiteness degree of $70 \%$ and higher.

However, the addition of large amounts of $\mathrm{TiO}_{2}$ is not economically efficient. On the other hand, it is necessary to use some fillers in order to reduce possible shrinkage deformations of slag materials based on slag alkali-activated cements. Moreover, such fillers should not reduce the degree of whiteness.

For this, a set of experiments was carried out aimed at identifying the combined effect of various bleaching agents. Based on the results of previous studies, $\mathrm{TiO}_{2}$, kaolin clay and $\mathrm{CaCO}_{3}$ were selected as such additives. The experiments were carried out according to a two-factor mathematical design. According to research results, $\mathrm{TiO}_{2}$ was recognized as the best whitening agent. 
The ranges of variation for all additives have been set according to previous results in terms of maintaining the required strength grades of 42.5 and 52.5. The maximum content of $\mathrm{CaCO}_{3}$ was taken to be $25 \%$, for kaolin clay $-15 \%$. The $\mathrm{TiO}_{2}$ content in the experiments was taken in the range of $2.5 \ldots . .5 \%$.

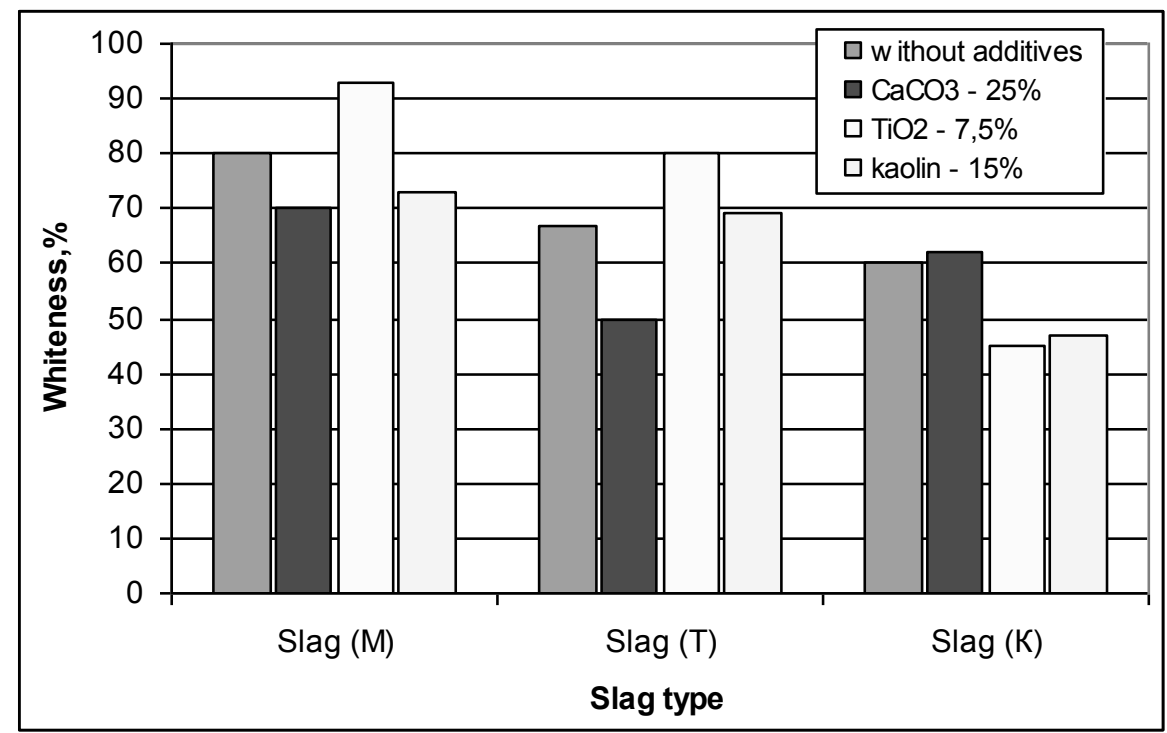

Fig. 2. The degree of whiteness of slag alkali-activated cement, depending on the type and amount of bleaching additives. The amount of sodium metasilicate $-10 \%$

The results of studies of the degree of whiteness of the investigated slag alkali-activated cements with $\mathrm{TiO}_{2}$ and calcium carbonate powder are shown in Fig. 3, and with $\mathrm{TiO}_{2}$ and kaolin in Fig. 4.

The analysis of the results obtained allowed us to show that in the case of the combined use of $\mathrm{TiO}_{2}$ and $\mathrm{CaCO}_{3}$, a degree of whiteness can be achieved, which varies within $85 . . .97 \%$, which meets the standard requirements for high-quality decorative materials.

The $\mathrm{CaCO}_{3}$ content in slag-alkaline cement made with slag (M) was the main one, and the titanium dioxide content was minor (corrective). And for slag-alkaline cement based on slag (T), the interaction of the aforementioned additives was important.

In the case of slag $(\mathrm{K})$, when the $\mathrm{TiO}_{2}$ content was 2.5 to $5.0 \mathrm{wt} . \%$, the calcium carbonate content was more important. After increasing the $\mathrm{TiO}_{2}$ content to 5.0...7.5 wt. \%, The combination of the above additives was the most effective. The combination of kaolin and white $\mathrm{TiO}_{2}$ pigment also made it possible to obtain a high degree of whiteness of the studied alkali-activated slag cements. It can be concluded that the whiteness of the slag alkali-activated test cements increased rapidly with increasing titanium dioxide content, while the addition of kaolin clay allowed the whiteness to be changed only within narrow limits.

The experiments carried out allow us to conclude that slag-alkaline cement made from slag (K) has an insufficient degree of whiteness compared to slag-alkaline cements made from slag (T) and slag (M). This can be explained by the different chemical composition of the feedstock, and first of all, by the presence of iron oxides contained in the slag: $0.35 \%$ - in the slag (M), $0.42 \%$ in the slag (T) and $1.65 \%$ in the slag $(\mathrm{K})$. Thus, it can be assumed that the content of iron oxide in the raw material is the main reason that explains why the whiteness tended to decrease. The small difference between the whiteness degree of slag-alkali cements made from slag (T) and slag (M) can be explained by the relatively small difference in the presence of iron oxide in these slags (Table 1). 

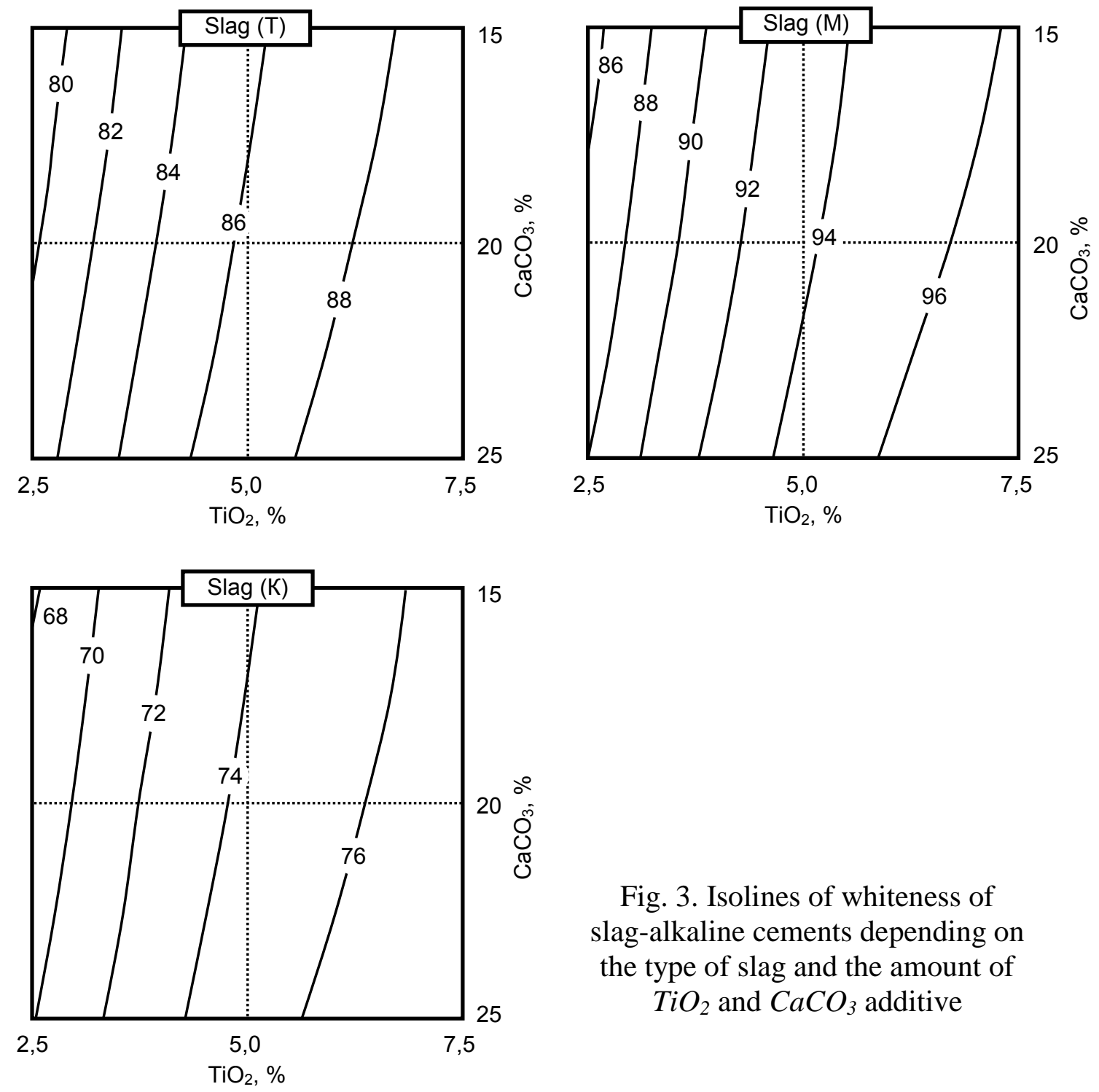

Fig. 3. Isolines of whiteness of slag-alkaline cements depending on the type of slag and the amount of $\mathrm{TiO}_{2}$ and $\mathrm{CaCO}_{3}$ additive

Influence of iron oxides on the whiteness of slag-alkaline decorative cements. The presence of iron oxides in slag-alkaline decorative cements can impair their whiteness for two reasons:

- due to the formation of compounds of the type $\mathrm{FeSO}_{4} \cdot 7 \mathrm{H}_{2} \mathrm{O}$ [13] and the acquisition of a blue-green color;

- due to the fact that iron oxides have a color from brown to dark brown, they thereby reduce the whiteness of the cement.

But if in the first case this color appears in the early stages of hardening and gradually disappears in air due to carbonization over the surface [17], then in the second case, the decrease in whiteness depends on the amount of iron oxides and can only be corrected with appropriate bleaching additives and/or the choice of slag low in iron oxides.

To reveal the role that $\mathrm{FeO}$ plays in relation to the whiteness of slag-alkali cements, the following experiment was performed - $\mathrm{FeO}$ powder was added to slag (M) to simulate slag compositions $(\mathrm{T})$ and $(\mathrm{K})$. The proportions of the optimal cement composition did not change.

The results are shown in Fig. 5. 

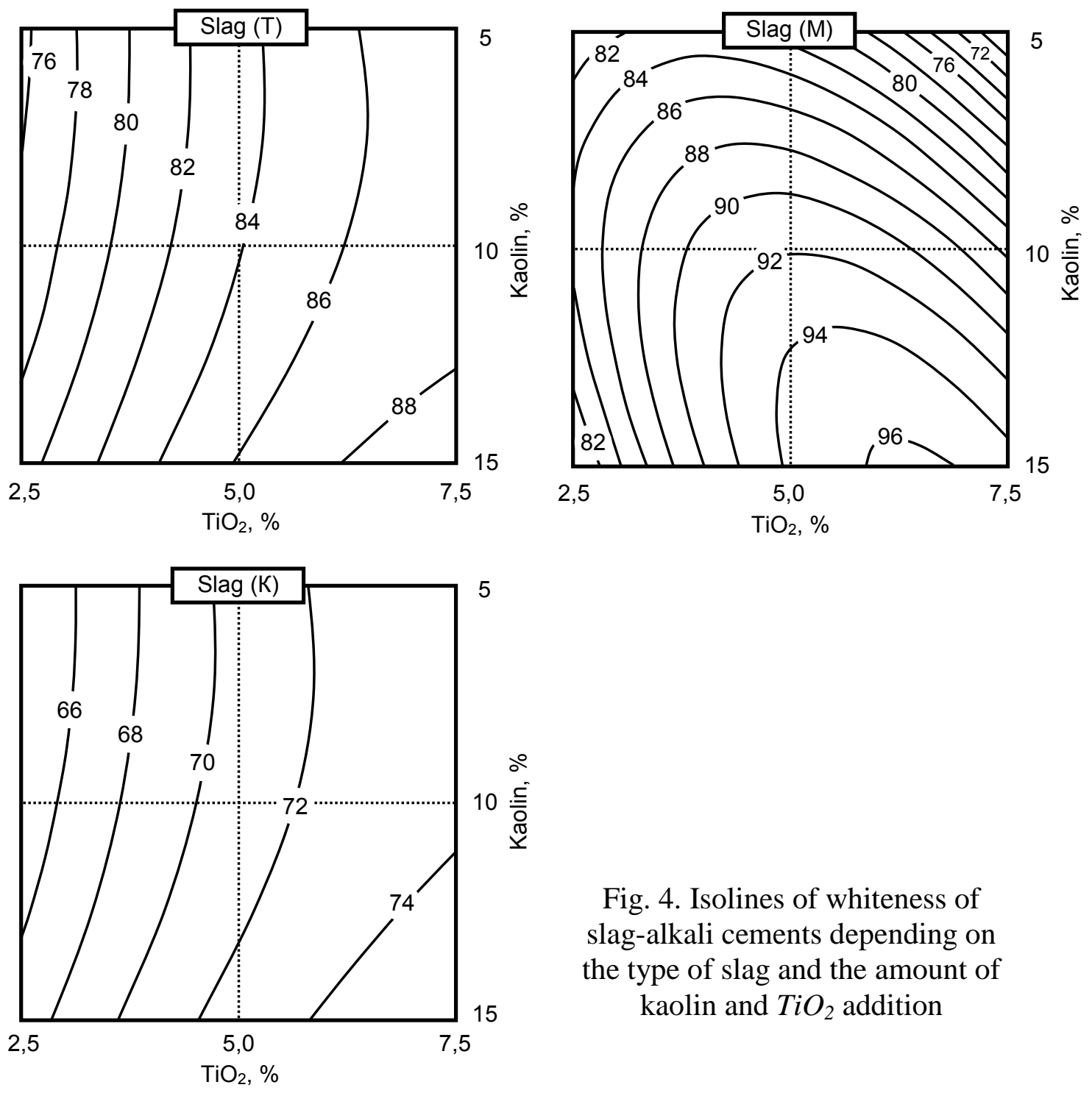

Fig. 4. Isolines of whiteness of slag-alkali cements depending on the type of slag and the amount of kaolin and $\mathrm{TiO}_{2}$ addition

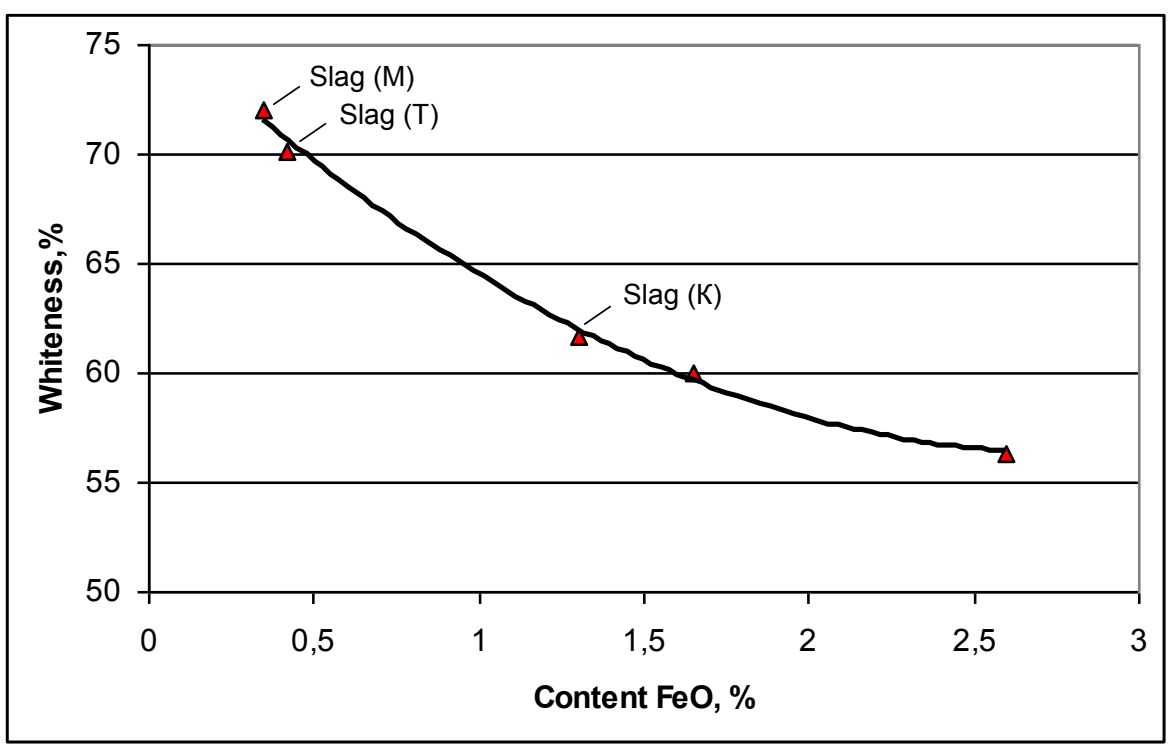

Fig. 5. Influence of $\mathrm{FeO}$ on the whiteness of alkali-activated slag cements. No whitening additives 
The results of this study allow us to conclude that with an increase in the $\mathrm{FeO}$ content in the slag, a decrease in the whiteness of the cement is observed.

Thus, the assumption about the role played by the composition of the slag and, in particular, the content of $\mathrm{FeO}$ in it for the degree of whiteness, was correct.

Conclusions. The research results lead to the following conclusions:

- The content of iron oxide in the raw material plays a decisive influence on the whiteness of alkali-activated slag cements. The easiest way to improve whiteness is to reduce the amount of iron oxides in alkali-activated slag cement. This can be realized by choosing slags with a low iron oxide content, grinding the slag in mills with ceramic lining and ceramic grinding bodies, and by introducing bleaching additives.

- The main corrective effect on the whiteness of alkali-activated slag cements is produced by $\mathrm{TiO}_{2}$. Its amount can vary depending on the required brightness of the final product and the content of iron oxides in the blast furnace slag. Some $\mathrm{TiO}_{2}$ can be replaced with white mineral additives (calcium carbonate and kaolin clay) without significant loss of whiteness. The use of $\mathrm{TiO}_{2}$ additives alone and in combination with $\mathrm{CaCO}_{3}$ and kaolin additives made it possible to obtain decorative slag-alkaline cements with a whiteness of $70 \ldots 97 \%$.

- The obtained decorative slag-alkali cements have a strength class of 42.5...52.5.

- A new method for determining the whiteness of decorative cements has been proposed by scanning the surface of cement samples, followed by measuring the degree of whiteness by comparing it with a reference sample with a whiteness of $98 \%$ in PhotoShop Soft.

- Further work will be aimed at determining the operational characteristics of slag-alkaline decorative compositions - adhesion, efflorescence, resistance to ultraviolet radiation, durability.

Acknowledgements. Authors also express their gratitude to the Ministry of Education and Science of Ukraine for financial support of this research that is carried out within the budgetary financing of topic with registration No 1020 U001010 and implementation period $2021 \ldots 2022$.

\section{References}

[1] V.M. Semenov, "Lakokrasochnye materialy dlya zashchity betonnyh i cementnyh poverhnostej", Lakokrasochnaya promyshlennost', no. 11, pp. 23-27, 2010.

[2] Bilij cement. Portal PP Budpostach. [Online]. Available: https://ppbudpostach.com.ua/a118411-belyj-tsement.html.

[3] L.A. Berezina, Z.A. Abdulberov, "Primenenie kaolina kompanii IMERYS Minerals v proizvodstve lakokrasochnyh materialov", Lakokrasochnye materialy $i$ ih primenenie, no. 1-2, pp. 61-65, 2009.

[4] Yu.S. Levashova, N.O. Kosenko, O.S. Lebedeva, "Doslidzhennya parametriv mikroklimatu primishen velikogo skupchennya lyudej", Naukovij visnik budivnictva, vol. 93, no. 3, pp. 217-22, 2019.

[5] G.S. Petrenko, "Sovremennye pigmenty i napolniteli dlya lakokrasochnoj promyshlennosti", Lakokrasochnaya promyshlennost, no. 9, pp. 30-36, 2010.

[6] P.V. Krivenko, "Alkaline Cements", materials First Intern. Conf. "Alkaline Cements and Concretes", pp. 111-129, 1994.

[7] P.V. Krivenko, O.N. Petropavlovsky, A.G. Gelevera, G.V. Vozniuk, V.I. Pushkar, "Promyshlennye shelochnye cementy i ih effektivnost", Nauchno-tehnicheskij sbornik "Aktualnye problemy stroitelstva", pp. 64-71, 2009.

[8] P. Krivenko, "Alkali-Activated Materials - 55 Years of Experience", Proc. of the International Conference on Alkali-Activated Cement and Concretes, pp. 1-5, 2014.

[9] C. Shi, P.V. Krivenko, Della Roy, Alkaline activated cements and concretes (in Chinese, Authorized translation from English): Monograph Taylor \& Francis, 2012.

[10] A. Fernández-Jiménez, I. Garcia-Lodeiro, O. Maltseva, A. Palomo, "Hydration mechanisms of hybrid cements as a function of the way of addition of chemicals", Journal of the American Ceramic Society, 102(1), pp. 427-436, 2019. 
[11] P. Krivenko, O. Petropavlovsky, O. Kovalchuk, A. Pasko, S. Lapovska, "Design of the composition of alkali activated Portland cement using mineral additives of technogenic origin", Eastern-European Journal of Enterprise Technologies, 4/6 (94), pp. 6-15, 2018.

[12] P.V. Krivenko, O.N. Petropavlovsky, V.I. Gots, G.S. Rostovskaya, "Alkali activation of Composite Cement", Ibausil. Internationale Baustofftagung 1, pp. 445-456, 2009.

[13] M. Chaouche, X.X. Gao, M. Cyr, M. Cotte, L. Frouin, "On the origin of the blue/green color of blast-furnace slag-based materials: Sulfur K-edge XANES investigation", J Am Ceram Soc. 100, pp. 1707-1716, 2017. doi:10.1111/ jace.14670.

[14] P. Krivenko, O. Petropavlvskyy, V. Puskar, L. Ostrovska, "Decorative alkaline cements", IV Intern. Symp: Non-Traditional cement \& Concrete, pp. 257- 265, 2011.

[15]P. Kryvenko, M. Sanytsky, T. Kropyvnytska, R. Kotiv, "Decorative multi-component Alkali Activated Cements for restoration and finishing works", Advanced Materials Research 897, pp. 45-48, 2014. doi:10.4028/www.scientific.net/AMR.897.45.

[16]P.V. Krivenko, O.Yu. Kovalchuk, "Upravlinnya dekorativnimi vlastivostyami luzhnih cementiv", Naukovij visnik budivnictva, 2(95), pp. 280-285, 2019.

[17]O.Yu. Kovalchuk, "Issledovanie karbonizacii shelochnyh betonov", Stroitelnye materialy, izdeliya i santehnika, no. 52, pp. 19-24, 2014.

\title{
ЗАЛЕЖНІСТЬ БІЛОСТІ ДЕКОРАТИВНИХ ШЛАКОЛУЖНИХ ЦЕМЕНТІВ ВІД ХІМІЧНОГО СКЛАДУ ДОМЕННОГО ШЛАКУ
}

\author{
${ }^{1}$ Кривенко П.В., д.т.н., професор, \\ pavlo.kryvenko@gmail.com, ORCID: 0000-0001-7697-2437 \\ ${ }^{1}$ Гелевера О.Г., к.т.н., доцент, \\ a-gelevera@ukr.net, ORCID: 0000-0002-6285-9780 \\ ${ }^{1}$ Ковальчук О.Ю., к.т.н., с.н.с., \\ kovalchuk.oyu@gmail.com, ORCID: 0000-0001-6337-0488 \\ ${ }^{1}$ Рогозіна Н.В., аспірант, \\ knubatbkv@ukr.net, ORCID: 0000-0001-9621-4246 \\ ${ }^{1}$ Київський національний університет будівництва та архітектури \\ пр. Повітрофлотський, 31, м. Київ, 03037, Україна
}

Анотація. Будівельна індустрія потребує все більшої кількості якісних декоративних цементів. Попит на них і вимоги до їх експлуатаційних характеристик постійно зростають. Але так як декоративні цементи базуються на білому портландцементі, то їх виробництво пов'язане 3 недоліками виробництва усіх клінкерних цементів - низькою екологічністю, високою енергоємністю і високою ціною. Вони не завжди здатні забезпечити отримання декоративних екологічних i комфортних покриттів 3 підвищеними експлуатаційними показниками. Крім того, багато країн його не виробляють і змушені імпортувати.

Ефективною альтернативою клінкерним декоративним цементам може бути декоративний шлаколужний цемент, який отримується з використанням промислових відходів. Він також дозволяє забезпечити ряд спеціальних властивостей - широкий діапазон кольорів, стійкість кольорів, високу міцність, високу адгезію, довговічність та багатьох інших.

Але проблемою, пов'язаною із застосуванням шлаколужних цементів у якості декоративних цементів з високими характеристиками білизни $(\geq 70 \%) \epsilon$ нестабільний хімічний склад шлаку і в першу чергу різна присутність у ньому оксидів заліза. Показано, що наявність оксидів заліза може знижувати білість декоративних шлаколужних цементів за рахунок синтезу в них сполук, які надають зразкам синьо-зеленого кольору і за рахунок присутності власне оксидів заліза, яким притаманний колір від коричневого до темно-коричневого.

У роботі показані закономірності впливу хімічного складу доменних шлаків на білість штучного шлаколужного каменю. Показані можливості отримання декоративних лужно- 
активованих цементів із широким діапазоном білості - від 70 до 97\%. Показані способи здешевлення шлаколужних декоративних цементів за рахунок використання комплексної відбілювальної добавки, де частина дорогого $\mathrm{TiO}_{2}$ може бути замінена каоліном або $\mathrm{CaCO}_{3}$. Запропоновано новий метод визначення білості затверділих матеріалів.

Ключові слова: декоративні цементи, лужно-активовані цементи, ступінь білості.

\title{
ЗАВИСИМОСТЬ БЕЛИЗНЫ ДЕКОРАТИВНЫХ ШЛАКОЩЕЛОЧНЫХ ЦЕМЕНТОВ ОТ ХИМИЧЕСКОГО СОСТАВА ДОМЕННЫХ ШЛАКОВ
}

\author{
${ }^{1}$ Кривенко П.В., д.Т.Н., профессор, \\ pavlo.kryvenko@gmail.com, ORCID: 0000-0001-7697-2437 \\ ${ }^{1}$ Гелевера А.Г., к.т.н., доцент, \\ a-gelevera@ukr.net, ORCID: 0000-0002-6285-9780 \\ ${ }^{1}$ Ковальчук А.Ю., К.т.Н., с.Н.с., \\ kovalchuk.oyu@gmail.com, ORCID: 0000-0001-6337-0488 \\ ${ }^{1}$ Рогозина Н.В., аспирант, \\ knubatbkv@ukr.net, ORCID: 0000-0001-9621-4246 \\ ${ }^{1}$ Киевский наииональный университет строительства и архитектуры \\ пр. Воздухофлотский, 31, г. Киев, 03037, Украина
}

\begin{abstract}
Аннотация. Строительная индустрия требует все большего количества качественных декоративных цементов. Спрос на них и требования к их эксплуатационным характеристикам постоянно растут. Но так как декоративные цементы базируются на белом портландцементе, то их производство связано с недостатками производства всех клинкерных цементов - низкой экологичностью, высокой энергоемкостью и высокой ценой. Они не всегда способны обеспечить получение декоративных экологических и комфортных покрытий с повышенными эксплуатационными показателями. Кроме того, многие страны его не производят и вынуждены импортировать.

Эффективной альтернативой клинкерным декоративным цементам может быть декоративный шлакощелочного цемент, получаемый с использованием промышленных отходов. Он также позволяет обеспечить ряд специальных свойств - широкий диапазон цветов, стойкость цвета, высокую прочность, высокую адгезию, долговечность и многих других.

Но проблемой, связанной с применением шлакощелочных цементов в качестве декоративных цементов с высокой белизной $(\geq 70 \%)$ является нестабильный химический состав шлака и, в первую очередь, разное присутствие в нем оксидов железа. Показано, что наличие оксидов железа может снижать белизну декоративных шлакощелочных цементов за счет синтеза в них соединений, которые придают образцам сине-зелений цвет и за счет присутствия собственно оксидов железа, которым присущ цвет от коричневого до темно-коричневого.

В работе показаны закономерности влияния химического состава доменных шлаков на белизну искусственного шлакощелочного камня. Показаны возможности получения декоративных щелочно-активированных цементов с широким диапазоном белизны - от 70 до 97\%. Показаны способы удешевления шлакощелочных декоративных цементов за счет использования комплексной отбеливающей добавки, где часть дорогого $\mathrm{TiO}_{2}$ может быть заменена каолином или $\mathrm{CaCO}_{3}$. Предложен новый метод определения белизны затвердевших материалов.
\end{abstract}

Ключевые слова: декоративные цементы, щелочно-активированные цементы, степень белизны.

Стаття надійшла до редакції 30.04.2021 